\title{
The Role of Low-cost Private Secondary Schools in Rural Kenya Under the ‘Free Secondary Education POLICY'
}

\author{
Miku Ogawa ${ }^{a}$ \\ Osaka University
}

\begin{abstract}
This study aims to understand the role of private secondary schools in rural Kenya under the Free Secondary Education Policy. Data were collected from four private schools over two months in 2018 and 2019. All the schools had experienced instability due to low enrolment, particularly after the policy was implemented in 2018. The decline in the schools' income also affected the quality of education. However, the results suggest that some students prefer to complete their education at private schools as low-expense-boarders or as beneficiaries of fee discounts. Other students choose private schools to avoid overcrowded classrooms and travel far, especially when excluded from public schools. This study argues that despite limited learning resources, private secondary schools in rural Kenya have an important place in the public education system outside of the academic pyramid of public schools.
\end{abstract}

Keywords: private schools; public schools; Kenya; low-cost; free education

\section{Introduction}

Why is there a demand for private education when public school is free in developing countries? According to James (1993), limited public spending on schooling in developing countries creates an excess demand in the private sector at the secondary level. The author also predicted that as the public education sector expands, people previously involuntarily excluded from public schools will be able to find places to study; thus, excess-demand-driven private schools have lost their need and will be crowded out.

Kenya was one such country, with very limited public spending on secondary education. However, since 2008, the government has gradually increased its support for public schools, leading to a secondary education policy in 2018 that provides free education. Given this situation, how have the excess-demand-driven private schools been affected? This study aimed to examine the state of private schools since public schools were made free and to discuss their role in the Kenyan education system.

Kenya has a basic education system consisting of eight years of primary education and four years of secondary education. Primary education is reaching full enrolment ratio, with a net enrolment rate (NER) of $92.4 \%$ and a gross enrolment rate (GER) of $104 \%$, as of 2018 (RoK, 2019). Opportunities for secondary education are also expanding, with $53.2 \%$ NER and $70.3 \%$ GER, as of 2018 (RoK, 2019).

Abolishing school fees is one of the most powerful interventions for promoting education in developing countries. Yet, despite the free public education by the government, studies have revealed the emergence of private schools during this period, even in countries other than Kenya. Particularly, in the context of primary education, studies have indicated that private schools are rapidly proliferating in South Asia and Sub-Saharan Africa (Bold, Kimenyi, \& Sandefur, 2013; Tooley, Dixon, \& Stanfield, 2008). For example, in 2002, in Kenya, there were 1,441 private primary schools.

Correspondence can be directed to: ogawa.miku.39@gmail.com 
By 2018, this number increased to 13,669 (RoK, 2006; 2019) The percentage of private schools in secondary education is not as high as in primary education, although it is still around $15 \%$ (RoK, 2019).

Some studies, including those conducted in Kenya, have discussed the reasons for the growth of private schools and their role in education (Alcott \& Rose, 2016; Oketch et al., 2010). However, since most of these studies have mainly focused on primary education, little is known about how private secondary schools influence the secondary education system (Srivastava \& Walford, 2007; Srivastava, 2013). Additionally, many of the motivations for choosing a private school were examined via household surveys, whereas only a few were examined via school-based fieldwork (Akaguri, 2014; Alderman, Orazem \& Paterno, 2001; Chudgar \& Quin, 2012; Woodhead, Frost \& James, 2013). There is, therefore, a lack of discussion on how secondary education is provided in private schools. To better understand the role of private secondary schools in Kenya, this study examines the influence of the free secondary education policy on private schools. It seeks to identify whether there are reasons, in addition to the inadequacy of public schools, that motivate students to choose private education.

\section{Background}

\section{The Demand for Private Schools}

To understand the growing need for private schools, James (1993) analyses primary and secondary education data from 12 developed and 38 developing countries. The author suggests that two kinds of demands-excess-demand and differentiated-demand-have motivated the growth of private education. According to James, the limited public system in developing countries creates an excess- demand for private schools, even if they are considered inferior. But, on the other hand, the differentiated-demand-driven private schools that survive in countries with adequate educational opportunities are likely to be considered academically or ideologically superior (James 1993). In other words, while excess- demand for private schools is created for people who would prefer to enrol in public schools but are unable to find a place, differentiated- demand for private schools comes from people who seek preferred education even if public schools are available.

The history of educational expansion in Kenya reveals that private schools were dominant, particularly in rural areas with fewer public schools (Sifuna \& Oanda, 2014), suggesting they were excess-demand-driven. This is similar to other countries that also rely on private schools to provide educational opportunities. For example, in India, the unavailability of public schools has forced parents to choose private schools to ensure their children receive education (Mousumi \& Kusakabe 2017). Similarly, in urban Kenya, parents prefer sending their younger daughters to private schools nearby, given the unsafeness of the slums that obstruct the route to the faraway public schools (Ohba, 2013).

Another issue to consider regarding free education is that these schools demand some money from the pupils. A Rwandan study posits that 'hidden costs' charged by public schools under the free education policy were a constraint to continued schooling (Williams, Abbott \& Mupenzi, 2015). In a case study on the slums in Nairobi, Abuya, Oketch and Musyoka (2013) found that several pupils dropped out of public school due to their incapacity to pay the fees. In this case, parents chose to enrol their children in low-cost private schools that were cheaper than public schools. In this sense, private schools can be regarded as key to realising the 'education for all' agenda.

Some studies have also found that the emergence of private schools is an outcome of the desire to pursue higher quality education (Bold, Kimeny, \& Sandefur, 2013; Bold et al., 2014). Studies from Asia similarly reveal that people prefer private schools for this reason. For instance, a study in India indicated that private school students have better learning outcomes than public school students, even after accounting for their socioeconomic status and other characteristics (Muralidharan \& Sundararaman, 2015). Mousumi and Kusakabe (2017) noted that parents in India do not send their children to public schools to keep them away from environments where drug abuse, violence, and abusive language are prevalent. Studies in Kenya also suggest that some parents prefer private 
schools because free education has caused overcrowding in public school classrooms (Nishimura \& Yamano, 2013; Somerset, 2009; Zuilkowski et al., 2018). Another study revealed parents' distrust in public schools; Zuilkowski et al. (2018) found that parents perceive public schools as a last option through a case study in Kenya. The study revealed that parents perceive public schools as unsafe because most students there belong to very low-income families. According to these findings, it can be inferred that students who do not wish to attend public schools prefer private schools. All of these preferences contribute to differentiated-demand-driven private schools.

To summarise, private schools have grown mainly because public schools are unable to accommodate the rising educational opportunities. In addition, the quality of education is also different from that in public schools. These reasons correspond to the two demands that James (1993) identified about the increase in the number of private schools.

\section{The Diversity of Private Schools and their Role in the Inequality Gap}

Private schools have grown in response to the two aforementioned demands; both, however, have been criticised for being actors that increase inequality, as the expansion of private education has widened the inequality gap between the wealthy and the underprivileged families. For example, excess-demand-driven private schools with low-quality education widen the inequality gap between richer students who can attend public schools and poorer students who can only attend private schools; whereas differentiated-demand-driven private schools widen the inequality gap between richer students who can afford to attend private schools and the poorer students who cannot (Alcott \& Rose 2016; Bhatta, 2014; Härmä, 2011; Ohba, 2013; Oketch et al., 2010; Singh \& Bangay, 2014; Srivastava, 2013; Woodhead, Frost \& James, 2013).

Exemplifying the latter, a comparative study in the three East African countries, Tanzania, Kenya, and Uganda, indicates that although private schooling improves children's chances of learning the basics, it does not bridge the gap in learning inequalities between the wealthy and the underprivileged. The underprivileged are much less likely to be enrolled in private schools in each of the three countries (Alcott \& Rose, 2016). Another study from Nepal highlights inequality, whereby middle-income households abandon public schools in favour of private ones (Bhatta, 2014). Thus, educational inequality exists between wealthy and low-income families and between the poor and the poorest of the poor (Akaguri, 2014; Alcott \& Rose, 2016; Oketch et al., 2010). Studies from India reveal that relatively poorer households succeed in accessing private schooling; however, the most marginalised groups have no access to low-cost private schools (Härmä, 2011; Singh \& Bangay, 2014; Srivastava, 2013; Woodhead, Frost \& James, 2013).

In contrast, some studies have indicated that private schools play a role in bridging the educational inequality gap. For example, a comparative study by Heyneman and Stern (2014) focusing on private schools that cater to children from low-income families noted the opportunities offered by private schools that public schools cannot provide. It focused on low-fee private schools in Jamaica, Kenya, Tanzania, Ghana, Indonesia, and Pakistan, assessing the reasons for their increased demand. In their analysis, the difference in cost between a free public school and a low-tuition private school was modest in some countries. Thus, according to the study, it may be less expensive or even more cost-effective for some low-income families to privately educate their children. Further, in three countries, Tanzania, Jamaica, and Kenya, private schools often operate as miniature service agencies, offering education to children without families or to those from families that could not pay the full, or any, tuition (Heyneman \& Stern, 2014).

Another study in Pakistan suggests that private schooling can prevent the mismanagement of public funds. In developing countries, public educational expenditure is often handled inefficiently; for example, providing school buildings when not required, paying unqualified or underperforming teachers, and providing inadequate and limited school supplies (Alderman, Orazem \& Paterno, 2001). The study concluded that private schools should receive a public subsidy since this can improve both access to schools and quality education at a low cost. 
The discussion above reveals no single answer regarding whether private schools contribute to or reduce the inequality gap. It is also not possible to conclusively state that private schools are inferior or superior to public schools. In some instances, low-cost private schools have been found to produce low-quality education, whereas, in other instances, their output has exceeded top-quality government schools (Heyneman \& Stern, 2014). Chudgar and Quin (2012) suggest that diversity in private schooling quality can affect learning outcomes. Children at low-cost private schools can perform worse than those at public schools. Similarly, children at public schools can experience a learning deficit when compared to more expensive private schools.

Perceptions of private schooling may differ even when a study targets the same location. For instance, a study in Nairobi revealed that low-cost private primary schools were significantly more expensive than public schools (Zuilkowski et al., 2018). In contrast, another study showed that some public primary schools would collect user fees, making them more expensive than low-cost private schools (Abuya, Oketch \& Musyoka, 2013). Further, school fees among private schools differed, depending on the school management policy. Some schools functioned on a profit-based business model, while others were financed through charity and contributions (Ohba, 2013). Some private schools are expensive, with only wealthy families opting for them, whereas others are low-cost and accept children from vulnerable families.

Srivastava and Walford (2016) note a need to refine our conceptualisations of the different types of private schools that operate in the Global South and the nature of their engagement to discuss the efficacy of those schools the best way to mitigate social inequities. Even the meaning of 'low cost' among the studies on 'low cost/fee private schools' has no agreement (Tooley \& Longfield, 2016). Considering the diversity of private schools and understanding the actual situation, it is necessary to reveal how and why school leaders operate the institution and why students study there.

\section{The Private Sector and Secondary Education in Kenya}

In Kenya, public secondary schools are not uniform and are divided into four vertical categories: national, extra-county, county, and sub-county schools, based on their administrative level and merit (Nyangweso, Maiyo \& Kati, 2019). The topmost category is the national school, which offers the best quality education for a limited number of students, selected based on their primary leaving examination results. Most national schools and extra-county schools are boarding schools and predominantly same-sex ones. These boarding schools are regarded as the best option, compared to community-based private schools that mushroom to compensate for the lack of public boarding schools (Gichana, 2021).

Sub-county schools are at the bottom of the public categorisation and have recently begun mushrooming, contributing significantly to increasing access to secondary education. They provide a day school option that does not require boarding fees, which was a major burden for parents (Wanja, 2014). Although sub-county schools are categorised as the lowest, some private schools in rural areas are regarded even lower in academic achievement in graduate examinations. Sub-county schools, often unofficially, set minimum scores for students to qualify for admission; consequently, some students were rejected (Ogawa, 2017). Additionally, before implementing the free education policy in 2018, most private schools in rural areas were cheaper than public schools. Resultantly, private schools in rural areas accepted children who could not enrol in public schools (Oketch \& Somerset, 2010).

The quality of education provided by private secondary schools is generally regarded as poor; unlike in the primary education sector, there are only a few top private secondary schools in Kenya (Oketch \& Somerset, 2010). The majority of private secondary schools in rural areas operate as an unwanted alternative to public secondary schools, implying that financial insufficiency and low academic achievement forced students to enrol in private secondary schools.

However, the situation has gradually been changing. The government of Kenya aimed for a full transition of students from primary to secondary education and introduced the free secondary 
education policy in 2018. Although the government had provided a capitation grant to secondary schools under the banner of free education since 2008, the amount was insufficient to eliminate school fees. Therefore, in 2008, the government began allocating 10,265 Kenyan Shilling (KES) per student to public secondary schools annually and increased this amount to 12,870 KES in 2015 ( 1 KES is approximately 0.009 US Dollars). However, the government required contributions from parents and guardians up to 9,374 KES for day scholars and 53,553 KES for boarding scholars (RoK, 2015 ) in addition to the lunch fees. Finally, in 2018, this allocation doubled to 22,244 KES to cover the deficit since 2015, enabling day scholars to attend public secondary schools free of cost, except for lunch. This 2018 policy implementation was called 'truly' free education or 'full' free education. Additionally, sub-county schools had to accept students wishing to join secondary school, regardless of their scores, to ensure a $100 \%$ transition from primary to secondary education (Ministry of Education, Science and Technology, 2015).

This policy increased access to secondary education for all primary school leavers in 2018. Students with low marks too were able to enrol in public schools as the cheapest option. These governmental reforms allowed all prospective students to attend less expensive public day schools. In light of this discussion, then, what motivates students to choose private schools? What role do private schools play in rural Kenya?

According to the literature on primary education (Abuya, Oketch \& Musyoka, 2013; Zuilkowski et al., 2018), private schools are diverse. The present study, thus, focused on the private schools offering secondary education and attempted to understand the role of low-cost, private secondary schools in rural Kenya when a 'truly' Free Secondary Education Policy is in place. The study aimed to do this by first identifying the state and challenges of low-cost private schools under the free education policy, paying close attention to their diversity, and second, examining the reasons students joined these private schools. This was done so that private secondary schools in Kenya, following the free education policy, could be analysed by applying the two types of demand identified by James (1993).

\section{Methodology}

\section{Fieldwork}

This qualitative study used the case study method. It adopted a cross-sectional case-oriented approach, first examining aspects of each case (i.e. a school) and then conducting a comparative analysis of a small number of cases (i.e. all schools). As a result, the case study might be illustrative rather than representative. However, the strength of such a case study lies not in generalising percentages from specific findings to a wider population (Cohen, Manion \& Morrison, 2018; Yin, 2018), but rather in revealing the details of the situation in a specific context (Morse \& McEvoy, 2014). To this end, this study analysed qualitative descriptive data gathered through fieldwork.

Data were collected from four private schools in a sub-county of Busia County, Western Kenya (referred to as X sub-county), over a period of two months: six weeks in February \& March 2018, \& two weeks in March 2019.

Due to its political history, the western part of Kenya has lagged in educational reforms. Consequently, the region is currently experiencing a rapid expansion of education. $X$ sub-county, the focus of this study, covers an area of about $238 \mathrm{~km}^{2}$ (Busia Country Government, 2014) and is located about $20 \mathrm{~km}$ from the centre of Busia County. It experiences the highest rainfall in Busia and follows intensive agricultural practices. However, in recent years, drought and declining soil fertility have been affecting agricultural productivity (MoALF, 2016).

The data available at X sub-county's education office and the office of the Constituency Development Fund provided an overview of the geographical development of secondary schools in the target area. The research was conducted mainly through observation and interviews. The author spent more than a week in each school, observing teachers and students in their classrooms. Occasionally, when asked, helping teach some parts of the lesson or providing advice regarding 
examinations. In addition, the author interacted with the students and teachers during breaks. Observations of student and teacher behaviour and interactions helped establish a preliminary knowledge base, using which interview themes and questions were modified intermittently.

Further, the author has prior research experience in this region; annual visits since 2014 (total length of stay was about eight months, the total number of public schools visited was 21) helped build rapport with the participants of the study and glean a better understanding of public schools in that area. In this study, five public schools were also visited in 2018 for comparison with private schools. These five public schools (one of which was a boarding school) were in close proximity to the private schools under study.

\section{Data Analysis}

A semi-structured interview lasting one or two hours was conducted to understand the efforts to manage schools made by the principals and the directors/owners. Questions were asked about the management of each school, the process of establishment and development, relationships with the community and parents, and other school-related matters. Key questions include how the school was established and managed, what changes had been made since the policy was introduced, how the school responded to its current challenges, and what respondents thought was positive about their private school. Interview questions were modified to accommodate the context of the participants' narratives. Semi-structured interviews were recorded when allowed.

In each school, around five teachers and ten students were also interviewed. Most teachers in each school were interviewed when they were available. Students for the interviews were randomly selected from among those who volunteered to talk with the researcher. The author asked those who behaved or spoke in a peculiar way during the observation questions to gauge the reasons for these peculiarities. Unstructured interviews with open-ended questions were employed to understand teachers' motivations and perceptions. Students were asked questions to learn about their academic background, for example, whether they had ever dropped out or transferred and their reasons for enrolling in a private school.

Follow up interviews were also conducted with directors/owners, principals, teachers, and students to gain further insight for triangulation, thus ensuring its validity. The questions were modified by conducting multiple visits to each school; in both 2018 and 2019, the author reviewed the data obtained after visiting all the targeted public schools; the author revisited these schools to conduct further fieldwork, following up on any questions that were missing or required confirmation. The author also cross-checked the data obtained from these interviews and observations with those obtained from the Education Office.

The interviews were conducted mainly in English (the official language of Kenya), with Swahili (the national language of Kenya) used as a supplement. At the time of the fieldwork, the author's proficiency in Swahili was at the level of basic daily conversation and short speech. At school, the conversations between students and teachers during break times were conducted in Swahili and English. The author confirmed what was said by taking an active part in conversations and being aware of the flow of conversations. Whenever a word was unclear, the author confirmed it with the respondent. Everyday conversations formed the basis for unstructured interviews. The findings from participant observations and interviews were written as fieldnotes reconstructed after conversations with participants during breaks and classes.

Before the analysis, the recorded interviews were transcribed. The transcription memorised conversation and notes from participant observation were triangulated to check whether the author's semantic interpretation was valid by asking different questions about the same topic in different ways or checking with other participants. The author analysed both interviews and observations according to Braun and Clarke's general guidelines of thematic analysis (2006). Thematic analysis is a method for identifying, analysing, and reporting patterns (themes) within data (Braun \& Clarke, 2006). 
This study employed an inductive thematic analysis, a process of coding the data without trying to fit it into a pre-existing coding frame or the researcher's analytic preconceptions. This analysis is data-driven. The author systematically worked through the dataset, giving full and equal attention to each item, and identifying interesting aspects that may have formed the basis for repeated patterns (themes). Coding was done manually, using highlighters to indicate potential patterns of data. The patterns were organised under two major themes: the challenges of private schools and motivation to attend those schools following policy implementation.

The ethics review board approved the study of the research institute to which the author belongs. Every consideration was given to ensure that the study participants were not physically, psychologically, or socially harmed. Additionally, a research permit was obtained from Kenya's National Commission for Science, Technology, and Innovation. Particular attention was paid to the handling of personal data. To avoid participant identification, anonymity is maintained throughout the manuscript.

\section{Profile of Schools}

In 2019, X sub-county had 23 secondary schools. Among these, 2 were private schools, and 21 were public schools (18 sub-county schools, two extra-county schools and one county school). Extra-county schools accepted only boarding scholars, whereas the county school accepted day and boarding scholars. In addition, most sub-county schools did not have dormitories, accepting only day scholars.

In 2018, there were three private schools in the sub-country. Of these, two closed down in 2019, after which a new school was established in the same year. Thus, between 2018 and 2019, there were four private schools in this region, accepting both boarders and day scholars. The private and public schools were located in the same neighbourhood, and all were accessible on foot.

Table 1: Demography of Sampled Private Schools

\begin{tabular}{|c|c|c|c|c|c|}
\hline & \multirow[t]{2}{*}{ Presence } & \multicolumn{2}{|c|}{$\begin{array}{c}\text { Number of students } \\
\text { (number of } 1^{\text {st }} \text {-year secondary } \\
\text { students) }\end{array}$} & \multicolumn{2}{|c|}{ Number of teachers } \\
\hline & & 2018 & 2019 & 2018 & 2019 \\
\hline School A & 2001-2018 & $41(3)$ & $\mathrm{n} / \mathrm{a}$ & 5 & $\mathrm{n} / \mathrm{a}$ \\
\hline School B & 2011-2018 & $43(6)$ & $\mathrm{n} / \mathrm{a}$ & 10 & $\mathrm{n} / \mathrm{a}$ \\
\hline School C & 2014- & $48(6)$ & $55(2)$ & 8 & 4 \\
\hline School D & 2003-2014, 2019- & $\mathrm{n} / \mathrm{a}$ & $12(12)$ & $\mathrm{n} / \mathrm{a}$ & 4 \\
\hline
\end{tabular}

Source: Author collected data from each school and the education office

\section{Case Study (School) A}

School A was established in 2001 as a branch of a private educational institution. The director came from another country but resided in Kenya. For political reasons, he had the school built near the residence of a Member of Parliament of that constituency. The quality of facilities in School A was better than other private and public sub-county schools. The classrooms had ceilings, tiled floors, and several windows. It performed well academically and ranked 6th among 15 schools in X subcounty in the 2014 final examinations for the time it functioned. However, after that year, academic performance gradually declined, and the school was unable to attract new students. Competition from a nearby sub-county school that ranked 4th in 2017 further affected school enrolments; finally, in 2018, there were only three students in the first year of secondary school. School A closed down in 2019. 


\section{Case Study (School) B}

The director of School B started a school for girls in 2009 in her house. She purchased some land in 2005 and built her house in the township area. She noticed that many girls who had dropped out of secondary school remained in the town, doing nothing. She wanted, 'To start a school up to the secondary level'. The school offered bursaries in 'very, very needy cases'. The fees of 10 boarding scholars and five-day scholars were decreased to less than half the fee charged for other students. These 15 students paid in kind; they brought what they could from home, such as milk and agricultural produce from their fields. The director said that the existence of her school was 'sustained by a heart willing to help the girls'.

As a management strategy, the director accepted high scores students by reducing or waiving the school fees. She believed that to survive, the school required two kinds of students: those who were poor but performed well academically and those who belonged to relatively wealthy families and preferred to study privately. The former group of students raised the academic performance of the school, which would attract more students. The latter indirectly assisted the former by paying their school fees.

Even though the school had an insufficient number of students, boys were not enrolled because the director felt the presence of boys would make the girls reticent, thus affecting them adversely. The school, however, closed in 2019, when it had only 15 students. In addition, although the school ranked 4th in 2016, their decreased mean score for leaving examinations caused a decline in the number of higher-fee-paying students.

\section{Case Study (School) C}

School C was established in 2014 and is managed by a local. It was initially established as a college to educate the pastors of the denomination. Since 2014, the school has run as a secondary school, which, during holidays, functioned as a Pastoral college. Similar to School B, ten students were sponsored by the school in 2018, based on the economic status of their families. The school interviewed the students to understand their financial condition and judge whether they could afford the school fees. However, the school management has since become unstable.

A challenge that School $C$ encountered was that of not being registered as an examination centre. This meant that students had to travel to another school to take their examinations, costing each student $100 \mathrm{KES}$. Although there was no examination fee, students of School C had to pay approximately 5,000 KES to the other school as boarding and lodging fees during the examinations. The results of the students who could not pay this fee were withheld, and they did not receive their certificates. Their annual fees in 2019 continued to be higher than public day schools. In 2019, there were only two first-year students at the secondary school.

\section{Case Study (School) D}

School D started in 2003 but closed down in 2014. It was re-opened in 2019, with only 12 students. The director of School D belonged to the neighbouring county and had worked in Nairobi before arriving in this county. According to the director, during the first phase of the school, more than 600 students were enrolled. However, the community around the school was not supportive, as most of the students came from outside the community. The school closed down in 2014, the director said, due to the former principal. However, the director hopes that the current principal could collaborate with the community because 'he comes from the same community'.

However, the school continued to face challenges from the community. The current principal explained, 'Neighbours are a bit reluctant to have a school again. They thought it might not work'. Although most students come from X sub-county, they travel from the farthest places. Students were aware of the corruption in the school that led to its closure in 2014 and said, 'The director did not pay salaries to teachers and fought against students'. The students feared to communicate with the 
director even though, at times, she allowed them to watch television in her room and distributed fruits. Although it was not clear what had happened between the director and the community, her reputation among the students was not positive.

However, the new principal was popular among students, as was evident from the students' feedback: 'Now, the principal runs the school, so it's much better. He is very good'. The students were satisfied that the school was run by a local principal rather than a disreputable director. The current principal had joined the school in 2019 after giving up his job as a government teacher in an extra-county school. A teacher in another school said, 'The principal of School D is a very good chemistry teacher. That is a reason people enrol their children there'. The principal did not earn much but believed: 'I cannot be paid. If you compare the income (to my previous job), that was much more. It (School D) is a platform to keep me busy'. He used his personal connections in the government to raise funds for student bursaries.

\section{Results and Findings}

\section{The Current State and Challenges in Private Schools}

\section{School Fees and Their Expenditure}

Although the fees varied from school to school, day scholars in private schools paid more than public schools. In contrast, boarding scholars in private schools paid less than students in public schools, except for School B as of 2018.

Table 2: Basic Information on the Income and Expenditure of the Sampled Schools

\begin{tabular}{|c|c|c|c|c|c|c|}
\hline & \multicolumn{4}{|c|}{ School fees (KES/year) * } & \multirow{2}{*}{\multicolumn{2}{|c|}{$\begin{array}{c}\text { Payment for teachers } \\
\text { employed by each school (KES/ } \\
\text { month) }\end{array}$}} \\
\hline & \multicolumn{2}{|c|}{2018} & \multicolumn{2}{|c|}{2019} & & \\
\hline & Day & Boarding & Day & Boarding & 2018 & 2019 \\
\hline School A & 11,000 & 20,000 & & & $10,000-15,000$ & \\
\hline School B & 20,000 & 42,000 & & & $6,000-13,000$ & \\
\hline School C & 15,000 & 24,000 & 15,000 & 27,000 & $4,500-7,000$ & $5,000-9,000$ \\
\hline School D & & & 18,000 & 30,000 & & 4,000 \\
\hline Public** & $7,000-10,000$ & 41,000 & $7,000-10,000$ & 41,000 & $10,000-18,000$ & \\
\hline
\end{tabular}

Notes: *approximate fees, **the nearest public schools

Source: Author collected data from each school

School A tried to set minimal school fees. However, the annual fee charged by the nearest public school in 2018 was 7,000 KES. School A reduced its fees from 34,000 KES to 20,000 KES and from 18,000 KES to 11,000 KES for boarding and day scholars, respectively; however, it could not compete with the nearby public school. The fees at School B were more expensive than at other schools; however, as discussed earlier, the school has introduced a fee exemption for students from poor families. In School C in 2018, day scholars were charged annual fees of 15,000 KES and boarding scholars, 24,000 KES, increased from the 2017 charges of 12,000 KES and 18,000 KES, respectively, to compensate for the decrease in the number of students (from 80 to 48). The strategy was different from that of School A. However, this increase could also have been a reason for some students leaving School C. Thus, the school was trapped in a vicious cycle, with a declining number of students and income. The principal described the harsh situation in private schools, saying, 'Government is really 
destroying private schools'. Lastly, in School D, the school fees were 18,000 KES for day scholars and 30,000 KES for boarding scholars. Only one student paid the complete amount. Four students never paid any fees.

\section{Decline in the Number of Students}

All the four schools studied saw a decline in enrolment after the 'truly' free secondary education policy was implemented in 2018. The policy resulted in students shifting to public schools that offered 'cheaper and better' education than private schools.

According to the principal of School A, the sharp decline in student numbers began after a public school was established in their neighbourhood in 2014. Similarly, School C lost more than half its students in 2018. Only five of them had cleared their dues before transferring. The number of first-year secondary students in the private schools surveyed ranged between 2 and 12. Compared with the nearest public school, the difference in student enrolment was significant: 85 students in the smallest school and 271 in the largest. A teacher in School A said, 'the rest come to this school', explaining that students who could not find a place in public schools enrolled in private schools.

The principals of all the surveyed schools believed that their schools were quite successful before the government implemented free education. They further stated that they were running the school as a business to make profits. However, once the number of students dropped, it was not easy to recover. A teacher at School A said, 'Performance [in the secondary school leaving examinations] decides [the prospects of private schools]. If you perform well, you can be a private school charging with high fees. But once you fail to get students/population, you are off. You cannot select [students who attain high academic marks]'. As a result of declining student numbers and financial difficulties, all schools had tried to compensate for the dwindling finances by reducing teachers' salaries and maintenance expenditures. This predicament is illustrated by the accountant from School C, who said, 'The school fees are for at least buying food and paying staff'.

\section{Insufficient Number of Good Teachers as an Outcome of Poor Working Conditions}

Instability was one of the challenges faced by private schools because finding good teachers was not as easy as with public schools, where the government assigned teachers. The remuneration for teachers also varied by school, where, in public schools, it varies according to the type of employment. Even so, the lowest range of monthly salaries for public school teachers was between $10,000 \mathrm{KES}$ and $18,000 \mathrm{KES}$ (Table 2). Some teachers in private schools, however, were offered less than half that salary. The lowest example was School D, where a teacher's salary was set at 4,000 KES. Procuring even that amount of money in School D was difficult; according to the principal, "Any single payment [however small the payment from students is], will be shared by the teachers". The director of School B also said apologetically, 'They [teachers] are very patient and understanding'.

Most teachers of the surveyed private schools were not highly qualified. This was different from public schools in X sub-county, where most of the teachers earned requisite diplomas and degrees before being employed. Apart from the insufficient school budget, this was also one of the reasons for low teacher remuneration in private schools.

Such employment conditions resulted in the frequent replacement of teachers. When asked about the number of teachers at the private schools, respondents answered, 'For now...' as though the number was not fixed. Most teachers considered their work in private schools a temporary job while waiting for another secure position. For example, in 2018, there were eight teachers in School C, but in 2019, only the principal was working in the school, and other teachers were replaced. He, too, was going to leave soon for a government teaching job. All teachers, including the principal, in School C, were younger than 30 years, and most of them were still studying. It is not sustainable to employ and retain good teachers in such unfavourable circumstances. 
Further, the principal of School C complained about the behaviour of young teachers. He pointed to a young male teacher stating, 'He is like a green snake in a green bush'. He said the teacher lied about being a university student and tried to establish inappropriate relationships with female students via private phone calls. Because of the teacher, the best schoolgirl had to leave school due to pregnancy. The teacher also sometimes sold school supplies to students, which were supposed to be free. In another case, a female teacher had eloped with her lover. Her mother visited the school to take her back home, but she had already left. The principal was disappointed that teachers, who should behave with maturity, were setting improper examples.

The shortage of English language teachers was also a huge challenge for private schools, as it is a compulsory subject. As a result, schools A, C, and D did not have proper English language teachers. Further, some teachers in Schools $C$ and $D$ were required to teach more than three subjects that were not their majors. Most were not even qualified in any subject.

Teachers in private schools face severe challenges at work, creating instability in the students' learning environment.

\section{Shortage of Basic Supplies Such as Food and Drink}

All four schools in this study provided cheaper meals than did public schools. In all the schools visited, food and drinks were separately ordered for the author. The ones served in these private schools were considered unsuitable for visitors like me; for example, the principal of School D asked, 'Would you be comfortable eating the same food as us?'

In School A, only hot water was served to students during the tea break, though other schools generally offered black tea with sugar. Schools A, C, and D offered only black tea to teachers, whereas milk and snacks were also served at public schools. In all four schools, the menu for lunch for the teachers was the same as for students; this differed from public schools, where meat was provided more frequently to the teachers.

The students in School D would always check what was being prepared in the kitchen, as the school lacked basic foods. In addition, the lunch menu was not fixed, as it was at other schools, and students here were always curious about what they would be served at mealtimes.

Schools had to try to reduce consumption to sustain themselves. However, students and teachers complained about the shortage of even basic supplies. While reducing the expense of daily meals was an easy way of saving money, it directly affected students' health, energy, and concentration levels.

\section{Reasons for Choosing Private Schools}

In most cases, private schools did not seem to be the best option for students. The negative aspects of private schools discussed in the previous section overshadow their benefits. This implies that, at first glance, the private secondary schools in this study were, as James (1993) points out, merely excessdemand-driven private schools, which can be recognised as an inferior alternative to public schools. In other words, they may be considered a type of school that is susceptible to being crowded out by introducing the free secondary education policy, enabling more accessible access to public schools.

However, interviews and participant observations revealed there were different reasons why students chose private schools. This section will analyse the results from interviews concerning students' motivation to attend private school and the results of participant observation, paying attention to the difference between excess-demand and differentiated-demand.

\section{Benefits of Flexible School Management}

This is an aspect that private schools work as a safety net. The findings in this section are based mainly on interviews with management, principals, and teachers. 
The fee structure of public day-schools seems to be the cheapest option. However, private schools could provide cheaper education because of their flexible management. For example, some students did not wear the designated school uniforms, even though they were in the final year of secondary school; this would not be allowed in public schools. It was a relief to those who could not afford to buy uniforms.

Flexible management also provides some adjustability around school fees. In School B, for example, $35 \%$ of the students received a partial or complete discount. The director of School B cited the case of a first-year girl from a poor family who they fully sponsored. The director explained that this student had cried while expressing her desire to study. In her primary leaving examination, this student had scored 311 out of 500, which was sufficient for her to enrol in the extra-county school. The director stated, 'Some students do not have any money to study. Other students pay for their fees'. She also cited a case of parents who donated sanitary pads to the poor students studying with their daughters. Thus, it can be said that a cross-subsidy mechanism exists in private schools. However, flexible management can also cause instability and result in the closure of private schools.

Students who receive discounts were not selected merely based on their financial background; they were required to have a strong passion for academics and show a certain level of academic achievement. School C illustrates the difficulties students sometimes faced due to inadequate support from the school. The school offered a partial or complete discount to $21 \%$ of the students. However, the principal and the school manager summoned a 24-year-old second-year student, Kevin, because he had never paid fees. Some parents were surprised to see such an 'old boy' in school, wearing the designated school uniform. Kevin had scored over 250 in his primary leaving examination, which had enabled him to enrol in a public school at that time. However, he was unable to join because his parents had divorced and moved away. Kevin could not pay his fees because he did not receive any support from his parents. His mother had gone to Uganda and his father to Nairobi. Both of them had remarried. He explained that they did not meet him because they had new families. He earned his daily meals through his livestock (three goats) and a small field, using the money from the livestock to pay his rent (500 KES per month) and treat his ailing grandmother.

Although he explained his difficulties, the principal and the manager were not convinced. They looked at Kevin's notebooks to see if he was serious about his studies. Whereas there were some words written, there were also grammatical mistakes, and he could not read them himself. Further, when the manager asked him a few simple subject-based questions, Kevin could not answer them. An angry principal then said, 'If you were a hard-working person, the school may have understood your situation. But you are not'. Kevin was warned that if he did not pay his fees, he would be expelled. He was not allowed to attend classes until he paid.

Whereas some private schools function to support those who cannot access educational opportunities in public institutions, the managements struggle with sustenance realities. Consequently, students who received a reduction in school fees were selected based not only on their financial situation but also on their academic ability and attitude towards learning.

Another benefit of flexible school management was the personal connections. For example, most of the sponsored students in School B were referred by the church; the director's husband, a pastor, was associated with the church. Similarly, other schools also accepted students related to the school cooks, watchmen, and teachers. Although private schools exercise a certain degree of flexibility in understanding students' circumstances and reducing their financial burden, they do not necessarily accept all referred students. Only those who were introduced through known sources or who showed any potential for excelling academically were enrolled.

The safety net function of these private schools was important. Previous research has shown that low-cost private schools fulfil a similar function through flexible management (Heyneman \& Stern, 2014). However, this function would not be necessary if public schools were adequately funded 
and policies were developed to include the poorest. In other words, the private schools required in this respect were excess-demand-driven schools.

\section{An Alternative to Public Boarding Schools}

Although the reasons to study in private schools cannot be categorised simplistically, there were significant differences between boarding and day scholars regarding this issue.

All private schools had boarding facilities, whereas the majority of public schools in X sub-county did not. In Kenya, top-ranking public schools, such as national and extra-county schools, where only a small number of students enrol each year, are boarding schools. Sub-county schools are more widespread, without boarding facilities. However, to become a boarder at a public school, students have to excel academically and have the funds to pay the boarding fee. As shown in Table 2, it is possible to become a boarder at a private school for $50 \%$ to $70 \%$ less cost than a public school. For example, a student who transferred to School D from an extra-county boarding school emphasised that she had been a 'superior school' student. Although she was not allowed to attend the former school because of her inability to pay the fees, she still wore the uniform from her previous school to School D. It allowed her to recall her status of having been a student at a superior school in the past. Those students who chose private schools as an alternative to public boarding schools attainted above average scores in their primary leaving examination.

In this case, private schools are an inferior alternative to public boarding schools; they cater to excess- demand for public boarding schools. Some boarding scholars at private schools mentioned that the high fees of public boarding schools were the only reason they chose private schools.

Contrarily, private boarders rated their schools higher than public day schools. For example, a boarding student from School A referred to a neighbouring sub-county public day school, charging an annual fee of 7,000 KES, as a 'cheap school'. She also explained that she was enrolled in a private school because of poverty, implying that her financial circumstances prevented her from enrolling in a public boarding school, placing the public day schools at a lower level. This suggests that she believes the quality of education in private schools is lower than that in public boarding schools, but higher than in public day schools.

In this sense, private schools with boarding facilities have a quality different from public day schools, which can be regarded as a differentiated-demand. Nevertheless, it is a demand that could be eliminated was there cheaper access to public boarding schools.

\section{Smaller-Sized Class, Better Quality}

In this next section, I examine the opposite: what is considered to be differentiated-demand. Some students explained that their private schools were better than the public day schools for which they had received admission letters. In reality, these sub-county schools were diverse. Some, such as the newer schools, had lower examination results than the public schools; however, in terms of learning materials and the qualification of the teachers, they were better than the private schools. Nevertheless, students enrolled in private schools believed in their superiority over public day schools.

In the private schools studied, since class sizes were smaller-the number of students per class was just over 10 in the largest classes-students were able to participate actively during their lessons. By contrast, in public schools nearby, students per class averaged 54, with 68 in the largest classes and over 40 in the smallest ones.

Participant observation in private schools revealed that every student in the classroom received an opportunity to answer and ask questions. Moreover, when they were given an exercise 
to complete, most of them attempted to solve it on the blackboard. Several students also pointed out this advantage of being able to learn freely in the classroom.

The smaller class size also allowed teachers to share students' progress with each other because the teachers knew all their students well. This is essential in private schools, where a wide range of academic abilities exist among the students. For example, in School D, 9 out of 12 students scored above 300 in their primary leaving examination, enabling them to enrol in extra-county schools. The remaining three were described as 'slow learners' by the teachers for scoring lower than 150 . Teachers would spell out even simple words, such as 'sin' and 'view', when they read out what students needed to write in their notebooks for these 'slow learners'.

Students received adequate opportunities to express what they could not understand and to confirm what they had understood. Teachers also called students by their name and gave them the opportunity to ask questions, asking, 'Do you have any questions?' to confirm if they had correctly understood the contents. This was found to be a valuable characteristic of private schools, often not available in the crowded classrooms of public schools.

The 'quality of education' here is not explicitly defined in terms of the average score of the final examinations in each school or the qualifications of the teachers in each school. However, it was agreed in the interviews with teachers and students and confirmed through observation that smaller class sizes ensured more opportunities for independent learning. This type of education is currently not possible in public schools, with their large capacity; in this sense, these private schools were supported due to differentiated-demand.

\section{Providing Contextual Needs}

This section analyses differentiated-demand from another point of view. Students who feel uncomfortable with the large class sizes of public schools or their circumstances often enrol in private schools. They prefer studying in private schools where classes are smaller and fewer students from the same community.

For example, School C has a high-ranked student with an A-grade in her Continuous Assessment Test in 2018. This student had completed primary school in 2010 and joined the secondary school after saving money for her education. She is a mother and is older than the other students. She did not want to study in a public school because of her circumstances. The same school has another student who received an $\mathrm{E}$ in his Continuous Assessment Test. This student has a crucial learning difficulty and prefers a smaller class size with empathetic teachers. A private school better catered to both their different circumstances.

Further, the manager of School C explained, 'Some of them [i.e. students] are expelled from other schools because of bad behaviour'. For example, in School A, a student always wore a knit cap to hide her hairstyle, which was prohibited. Whereas there are students in private schools who are not well-disciplined, teachers rarely mete out severe punishment. For example, some girls use the dormitory to change into tight clothes and wear make-up after classes. This is not the case in public schools, where corporal punishment is often used. Students recognise this. A student from School D proudly said, 'That's what I like about this school. You don't get that in a public school'. Students sometimes even make fun of their teachers, behaving like they were the teacher's younger sibling. However, students and teachers were friendly in the schools that were surveyed.

Thus, the cases of students who, due to individual circumstances, do not want to or cannot go to their local public school, even if it is cheaper, can be said to be those of differentiated-demand. The public day school would not meet this demand because it has the 'localness' and familiarity of its members, who all come from the same community since primary school. This does not constitute differentiated-demand in the sense that private schools are more academically advanced than public schools; rather, it is in the sense that private schools provide alternative educational opportunities that public schools cannot. Public schools cannot fulfil this role so long as they are designed to accept students from the local area. 


\section{Discussion}

This study found that private secondary schools in rural Kenya face numerous challenges. This is because public schools' free secondary education policy has led to a flow of students from private to public schools. Once the number of students declines, private schools find it difficult to select students based on academic merit; further, their reduced school fees limit the budget available for input into the quality of education. The result is a vicious circle of declining performance in the secondary leaving examinations, which leads to a further decline in the number of new students. This vicious circle, or the tendency of declining enrolments to correlate with lower performance in final examinations, has been noted in private schools and public secondary and special schools in Kenya (Nderitu \& Ngunju, 2014; Ogawa, 2017).

However, even though private schools are not generally deemed the best option, some students prefer them. Location and overcrowded classrooms are some of the reasons why students avoid public schools. Financial assistance offered by private schools also makes them a better option for some students; those who come from different backgrounds, with a wide range of motivation and capabilities, are supported in private schools. In this sense, it can be said that private secondary schools in rural Kenya provide people with diverse abilities educational opportunities that are not available in public schools.

James (1993) suggested two kinds of demand support the growth of private schools: one, the excess-demand that arises due to a lack of public schools, and two, the differentiated-demand, which refers to differentials in the quality of education. The literature from developing countries notes that these two demands exist because of the shortage/incapacity of public schools or as an opportunity for receiving quality education (Chimombo, 2009; Härmä, 2016; Mousumi \& Kusakabe, 2017; Nishimura \& Yamano, 2013; Somerset, 2009; Zuilkowski et al., 2018).

This study found that such demands for private schools were a mixture of both excess-demand because students cannot go to public schools. On the other hand, it is also a differentiate-demand because they receive a more inclusive education that they cannot attain in public schools.

This study demonstrates that Kenyan free education policies limit the functions of private schools. As long as some students seek private schools, support for the institutions must be provided in educational policy reforms. It is also important to note that even if the quality of education is higher in public schools, 'quality of education' is a concept that can be defined in many ways and is not necessarily determined solely by the qualifications of teachers or the results of examinations. Nevertheless, Kenya's policy of allocating per capita subsidies only to public schools in secondary education poses a serious challenge to private schools. Of course, this policy has contributed to opening public schools to day-scholars and the expansion of access to secondary education. However, it is not easy for private schools with limited resources to ensure students an effective learning environment.

As seen in the Sustainable Development Goals, varied support and multiple options should be available for a variety of individuals to ensure 'equity'. Some private schools have higher tuition fees than public schools, further increasing the inequality gap that needs to be corrected. Similarly, it may also be assumed that private schools without quality education can widen the education gap. Indeed, as many studies have pointed out, private schools may increase the inequality gap (Akaguri, 2014; Alcott \& Rose, 2016; Bhatta, 2014; Härmä, 2011; Oketch et al., 2010; Singh \& Bangay, 2014; Srivastava, 2013; Woodhead, Frost \& James, 2013). If more affluent segments receive a better-quality education in private schools, then investing more public funds in private schools will be criticised from the perspective of equity (Belfield \& Levin, 2002); however, the findings of this study do not indicate that this is the case. Rather, it reveals the various reasons some students are excluded from public schools; it suggests that additional funding for private schools is needed to provide more equitable educational opportunities. For some students, without private schools, it might be impossible for them to complete their education. 
In the Kenyan secondary school system, students are selected in top tier schools based on their academic ability (Nyangweso, Maiyo \& Kati, 2019). Whereas this is not limited to Kenya, students are sorted according to their aptitude at a certain level of education. In this sense, students enrolled in secondary education may have a variety of educational needs, not necessarily seeking only an academically competitive learning environment but also carefully addressing their learning tasks according to their interests and living their lives as students without worrying about gossip or hearsay. To guarantee the availability of such diverse learning environments, it is essential to facilitate private schools as a learning option separate from the academic pyramid of public schools. Heyneman and Stern (2014) also question whether improvements in the public sector can meet the private sector's demand. This is because private schools provide a service that is unavailable in publicly operated schools. If we consider the diversification of quality in secondary education, private schools do not merely increase inequality but actually have the potential to achieve substantive 'equity' by providing a variety of educational opportunities for various individuals.

Whereas in developed countries, there has been much discussion around alternative schools that can guarantee a variety of educational opportunities (Henrich, 2005), in developing countries, the focus has been on expanding mainstream education in public schools to solve the significant shortage of educational opportunities. However, this may not be enough to meet the diverse learning needs of different individuals, meaning that it would not be possible to provide an inclusive education system with equity. The deficiency of public schools refers to the shortage in their numbers and their limited capacity to accommodate diverse learner needs (Abuya, Oketch \& Musyoka, 2013). This study suggests that although some private schools may constitute private investments that can increase economic disparity among individuals, they can also serve as institutions that play a public role by ensuring equity and responding to individuals' needs by providing a wider variety of education.

\section{Conclusion}

It is challenging to maintain private schools under a 'truly' free education policy in rural Kenya. Although the number of students enrolled in private schools is sharply declining, some still prefer private institutions. Whereas public day schools seem the least expensive, private schools are an alternative for students with special circumstances. Some students prefer private schools to avoid the problems associated with overcrowding and the location of public schools. Students also avoid enrolling in local public schools or being denied admission for specific reasons, such as being older, pregnant, or suffering from behavioural or learning conditions.

One of the challenges of this study is, of course, the overwhelmingly small sample size and the insufficient examination of whether the demands identified in this study necessarily apply in other cases. Furthermore, this could be considered a relatively minor report in that it attempts to focus on the needs of the minority of those attending private schools. It can also be argued that the financial challenges faced in developing countries make it permissible to prioritise the spread of public schools first. Therefore, the needs of minorities for private schools cannot be addressed. Though they certainly constitute a minority, assuring the needs of the minority is essential in the age of the Sustainable Development Goals.

An analysis of the varied reasons students prefer private schools revealed a varied mix of financial, academic, residential, disciplinary, and other needs. Private schools not only compensate for the lack of places in public schools but also provide options to students who do not want to enrol in them. As explained by the director of School B, 'The purpose is different from public institutions. We also do our part in the community'. Further, private schools are flexibly managed, and some students are sponsored by the schools or indirectly supported by those students who pay their fees. In other words, private schools have an inbuilt mechanism of redistribution that helps provide a learning opportunity for the most vulnerable students.

However, the implementation of free education is hurting private schools that accept these vulnerable students and those excluded from public schools. This study found that some private 
schools were forced to close down and also had to limit the number of students they could sponsor due to a lack of resources. This study argues that private schools work as a safety net, accepting vulnerable children who public schools cannot absorb for various reasons. School education is not just for competing in academic tests. Private schools have a strong role to play in achieving 'education for all', including those falling outside the academic pyramid of public schools.

\section{Note:}

1 This work was supported by JSPS KAKENHI Grant Number16J00622 and 19 K23340.

\section{References}

Abuya, B., Oketch, M. \& Musyoka, P. (2013). Why do pupils dropout when education is 'Free'? Explaining school dropout among the urban poor in Nairobi. Compare: A Journal of Comparative and International Education, 43(6), pp. 740-762. DOI:10.1080/03057925.2012.707458

Akaguri, L. (2014). Fee-free public or low-fee private basic education in rural Ghana: How does the cost influence the choice of the poor? Compare: A Journal of Comparative and International Education, 44(2), pp. 140-161. DOI:10.1080/03057925.2013.796816

Alcott, B. \& Rose, P. (2016). Does private schooling narrow wealth inequalities in learning outcomes? Evidence from East Africa. Oxford Review of Education, 42(5), pp. 495-510. DOI:10.1080/03 054985.2016.1215611

Alderman, H., Orazem, P. F. \& Paterno, E. M. (2001). School quality, school cost, and the public/private school choices of low-income households in Pakistan. The Journal of Human Resources, 36(2), pp. 304-326. DOI:10.2307/3069661

Belfield, C. R. \& Levin, H. M. (2002). Education Privatization: Causes, Consequences and Planning Implications. Paris: UNESCO International Institute for Educational Planning

Bhatta, P., (2014). Public desire for private schooling in Nepal. In: I. Macpherson, S. Robertson \& G. Walford (Eds.) Education, Privatisation and Social Justice: Case Studies from Africa, South Asia and South East Asia. Oxford: Symposium Books, pp. 67-88.

Bold, T., Kimenyi, M. S., Mwabu, G. \& Sandefur, J. (2014). Can free provision reduce demand for public services? Evidence from Kenyan education. The World Bank Economic Review, 29(2), pp. 293-326.

Bold, T., Kimenyi, M. S. \& Sandefur, J. (2013). Public and private provision of education in Kenya. Journal of African Economies, 22(suppl_2), pp. ii39-ii56.

Braun V. \& Clarke V. (2006). Using thematic analysis in psychology. Qualitative Research in Psychology 3(2), pp. 77-101. DOI: 10.1191/1478088706qp063oa

Busia County Government (2014). County Fiscal Strategy Paper. Busia: Busia County Government.

Chimombo, J. (2009). Expanding post-primary education in Malawi: Are private schools the answer? Compare: A Journal of Comparative and International Education, 39(2), pp. 167-184. DOI: 10.1080/03057920902750442

Chudgar, A. \& Quin, E. (2012). Relationship between private schooling and achievement: results from rural and urban India. Economics of Education Review, 31(4), pp. 376-390. DOI: 10.1016/j. econedurev.2011.12.003

Cohen, L., Manion, L. \& Morrison, K. (2018). Research Methods in Education (8th ed.). New York: Routledge.

Gichana, M. C. (2021). Is it time to Abolish Boarding Schools in Kenya? Kenya Studies Review, 9(1), pp. 68-72.

Härmä, J. (2011). Low- cost private schooling in India: Is it pro poor and equitable? International Journal of Educational Development, 31(4), pp. 350-356. DOI:10.1016/j.ijedudev.2011.01.003

Härmä, J. (2016). Is there a private schooling market in poor neighbourhoods in Maputo, Mozambique? Exploring the role of the non-state education sector. Oxford Review of Education, 42(5), pp. 511-527. DOI:10.1080/03054985.2016.1215612 
Henrich, R. S. (2005). Expansion of an alternative school typology. Journal of At-Risk Issues, 11(1), pp. 25-37.

Heyneman, S. P. \& Stern, J. M. B. (2014). Low- cost private schools for the poor: What public policy is appropriate? International Journal of Educational Development, 35, pp. 3-15. DOI:10.1016/j. ijedudev.2013.01.002

James, E. (1993). Why do different countries choose a different public-private mix of educational services? The Journal of Human Resources, 28(3), pp. 571-592. DOI:10.2307/146161

Ministry of Education, Science and Technology (2015). National Education Sector 2013-2018: Basic Education Programme Rationale and Approach. Nairobi: MoEST.

MoALF [Ministry of Agriculture, Livestock and Fisheries] (2016). Climate Risk Profile for Busia County. Kenya County Climate Risk Profile Series. Nairobi: MoALF.

Morse, A. \& McEvoy, C. D. (2014). Qualitative research in sport management: Case study as a methodological approach. The Qualitative Report, 19(31), pp. 1-13 DOI:10.46743/21603715/2014.1032

Mousumi, M. A. \& Kusakabe, T. (2017). The dilemmas of school choice: Do parents really 'choose' low-fee private schools in Delhi, India? Compare: A Journal of Comparative and International Education, 49(2), pp. 230-248. DOI:10.1080/03057925.2017.1401451

Muralidharan, K. \& Sundararaman, V. (2015). The aggregate effect of school choice: evidence from a two-stage experiment in India. The Quarterly Journal of Economics, 130(3), pp. 1011-1066. DOI:10.1093/qje/qjv013

Nderitu, N. \& Ngunju, A. W. (2014). Subsidiary sources of funds to minimise financial constraints on school budget in Kenya. Mediterranean Journal of Social Sciences, 5(5), pp. 305-322. DOI:10.5901/mjss.2014.v5n5p305

Nishimura, M. \& Yamano, T. (2013). Emerging private education in Africa: Determinants of school choice in rural Kenya. World Development, 43, pp. 266-275. DOI:10.1016/j.worlddev.2012.1

Nyangweso, J. O., Maiyo, J. K. \& Kati, R. (2019). Effect of secondary school categorization on examination failure rates among public secondary school students in Kenya. Journal of Education and Practice, 10(33), pp. 8-13. DOI:10.7176/jep/10-33-03

Ogawa, M. (2017). Emerging inequality in the process of educational expansion in rural Kenya: Impact of the community on secondary school management. The Journal of International Development Studies, 26(2), pp. 113-130. DOI:10.32204/jids.26.2_113

Ohba, A. (2013). Do low-cost private school leavers in the informal settlement have a good chance of admission to a government secondary school? A study from Kibera in Kenya. Compare: A Journal of Comparative and International Education, 43(6), pp. 763-782. DOI:10.1080/0305 7925.2012 .733536

Oketch, M., Mutisya, M., Ngware, M. \& Ezeh, A. C. (2010). Why are there proportionately more poor pupils enrolled in non-state schools in urban Kenya in spite of FPE Policy? International Journal of Educational Development, 30(1), pp. 23-32. DOI:10.1016/j.ijedudev.2009.08.001

Oketch, M. \& Somerset, A. (2010). Free Primary Education and after in Kenya: Enrolment Impact, Quality Effects and the Transition to Secondary School. CREATE Pathways to Access Research Monograph 37 Falmer: CREATE University of Sussex.

RoK (Republic of Kenya) (2006). Economic Survey 2006. Nairobi: Kenya National Bureau of Statistics. RoK (Republic of Kenya) (2015). Fees Guidelines for Public Secondary Schools in Kenya. Nairobi: Ministry of Education, Science and Technology.

RoK (Republic of Kenya) (2019). Economic Survey 2019. Nairobi: Kenya National Bureau of Statistics.

Sifuna, D. N. \& Oanda, I. O. (2014). Historical and Contemporary Trends in the Development of Education in Kenya: Government Policy, Gender and Regional Dimensions. Nairobi: The Jomo Kenyatta Foundation.

Singh, R. \& Bangay, C. (2014). Low fee private schooling in India-more questions than answers? Observations from the Young Lives longitudinal research in Andhra Pradesh. International Journal of Educational Development, 39, pp. 132-140. DOI:10.1016/j.ijedudev.2014.08.004 
Somerset, A. (2009). Universalising primary education in Kenya: The elusive goal. Comparative Education, 45(2), pp. 233-250. DOI:10.1080/03050060902920807

Srivastava, P. (Ed.) (2013). Low-Fee Private Schooling: Aggravating Equity or Mitigating Disadvantage? Oxford: Symposium Books.

Srivastava, P. \& Walford, G. (Ed.) (2007). Private Schooling in Less Economically Developed Countries: Asian and African Perspectives. Oxford: Symposium Books.

Srivastava, P. \& Walford, G. (2016). Non-state actors in education in the Global South. Oxford Review of Education, 42(5), pp. 491-494. DOI:10.1080/03054985.2016.1217695

Tooley, J., Dixon, P. \& Stanfield, J. (2008). Impact of free primary education in Kenya: A case study of private schools in Kibera. Educational Management Administration and Leadership, 36(4), pp. 449-469. DOI:10.1177/1741143208095788

Tooley, J. \& Longfield, D. (2016). Affordability of private schools: exploration of a conundrum and towards a definition of 'low-cost'. Oxford Review of Education, 42(4), 444-459. DOI:10.1080/ 03054985.2016.1197830

Wanja, H. N. (2014). An understanding of the trends in the free secondary education funding policy and transition rates from primary to secondary education in Kenya. Journal of Educational and Social Research, 4(1), pp. 133-142. DOI:10.5901/jesr.2014.v4n1p133

Williams, T. P., Abbott, P. \& Mupenzi, A. (2015). 'Education at our school is not free': The hidden costs of fee-free schooling in Rwanda. Compare: A Journal of Comparative and International Education, 45(6), pp. 931-952. DOI:10.1080/03057925.2014.938611

Woodhead, M., Frost, M. \& James, Z. (2013). Does growth in private schooling contribute to Education for All? Evidence from a longitudinal, two cohort study in Andhra Pradesh, India. International Journal of Educational Development, 33(1), pp. 65-73. DOI:10.1016/j.ijedudev.2012.02.005

Yin, R. K. (2018). Case Study Research and Applications: Design and Methods (6th ed.). Los Angeles: SAGE Publications.

Zuilkowski, S. S., Piper, B., Ong'ele, S. \& Kiminza, O. (2018). Parents, quality, and school choice: Why parents in Nairobi choose low-cost private schools over public schools in Kenya's free primary education era. Oxford Review of Education, 44(2), pp. 258-274. DOI:10.1080/03054985.201 7.1391084 
